\title{
Web-Based Professional Vocabulary Learning with the High School Students
}

\author{
Natalia Bakhmat ${ }^{1 *[0000-0001-6248-8468]}$, Olha Chaikovska 2 [0000-0001-9161-4574] \\ ${ }^{1}$ Kamianets-Podilskyi National Ivan Ohiienko University, Kamianets-Podilskyi, Ukraine \\ ${ }^{2}$ State Agrarian and Engineering University in Podilia, Kamianets-Podilskyi, Ukraine \\ *Bahger.teacher@gmail.com
}

\begin{abstract}
The world demand for the English language is growing. The Ukrainian government has already recognized the importance of the foreign language to economics and society. However, the foreign language competence in humanitarian High School is rather high, while the students of technical universities display a low level of language proficiency. 96 first-year male students majoring in Agricultural Engineering, Electrical Power Engineering, Electrical Engineering and Electro mechanics were enrolled in this experiment. The pre-experimental questionnaire showed that the students of Engineering and Technical Department use technology mainly for socializing and entertaining. The present study aimed at changing the focus from entertainment to learning through Quizlet performance in professional vocabulary acquisition with engineering students. To identify the impact of Quizlet vocabulary learning platform on the achievements of EFL (English as a foreign language) learners, an experimental design study was applied for one semester at State Agrarian and Engineering University in Podilia. The results of the experiment showed that there is a difference between the mean scores of the EFL learners who were taught vocabulary skills via Quizlet and the students who were taught the same skills by using the traditional learning in the post-test. Furthermore, we consider Quizlet to be a perfect up-to-date digital vocabulary with audio and visual aids. The findings of the study revealed that male students do better in learning professional vocabulary through Quizlet than learning new words writing them down in the paper vocabulary notebooks. In addition, Quizlet can assist in improving student attendance and, consequently, benefit the academic success.
\end{abstract}

Keywords: quizlet, digital, learning platform, professional, vocabulary acquisition, engineering, Technical High School.

\section{INTRODUCTION}

Current sociological research demonstrated that the economic development of the country depends on the level of foreign language competence. Relationships in the sphere of economics, science, education, medicine can't exist without language fluency. Nowadays national and international companies prefer to hire specialists who speak at least one foreign language. Unfortunately, Ukraine is among the European countries where the level of language competency is very low. And that is why our country can't use its potential on a full scale. To improve the level of foreign language competence Ministry of Education of Ukraine, British Council in Ukraine, university representatives, social communities presented the concept of the English language development at universities. The concept negotiates the previous high school policy of "focusing on weaker students". To become a university student one should have competences and language as well according to determined standards. And only general obligatory entrance exam in a foreign language can improve the situation. The level of language competence will be determined by university entrance grades. Consequently, till 2023 only the students with B1 language level will have the opportunity to study at the university. Such measures may seem to be very strict, but they are going to change the image of a modern expert in engineering [1]. For example, in 2018 there were only 18 university majors with obligatory general foreign language testing for Master course, in 2019 - 32, in 2020 - more than 80 majors to pursue a Master's degree. What is important, a lot of specialties concern engineering. Among the factors that make language learning very important for engineering specialties, we can mention the following: 
globalization in professional and education spheres as well, the rapid development of ICT technologies in the international scientific and technological environment.

I teach English at State Agrarian and Engineering University in Podilia for students, majoring in Agricultural Engineering, Electrical Power Engineering, Electrical Engineering and Electro mechanics. The English language is an obligatory discipline. The main document our EFL learning is focused on is the syllabus that determines basic competences. Students majoring in Electrical Power Engineering, Electrical Engineering and Electro mechanics should acquire the following competencies: basic competences (BC) - foreign language knowledge and the ability to effectively communicate both at professional and social levels, the desire to further self-study, special competences (SC) the ability to use the foreign language in professional activities.
The analysis of $\mathrm{BC}, \mathrm{SC}$ in learning a foreign language with the specialties "Agricultural Engineering" [2] and "Electrical Power Engineering, Electrical Engineering and Electro mechanics" [3] showed that demands to a specialist in electrical engineering in the context of foreign language competence are high. The education and qualification curriculum considers a wide range of language competencies starting from understanding and interpreting the profession-based knowledge to realize the need for constant language learning. In reality, the syllabus in a foreign language for engineering specialties provides 5 credits for this subject and 4 credits for students of short-term study after colleges. Table 1 shows the number of study hours in a foreign language at the basic engineering specialties of the Engineering and Technical Department.

Table 1. Distribution of hours in a foreign language study for bachelor students

\begin{tabular}{|c|c|c|c|c|}
\hline Major & $\begin{array}{c}\text { Four-year } \\
\text { bachelor degree / } \\
\text { 240 ECTS }\end{array}$ & $\begin{array}{l}\text { Hours for } \\
\text { individual study / } \\
\text { Four-year bachelor } \\
\text { degree }\end{array}$ & $\begin{array}{l}\text { Three-year } \\
\text { bachelor degree / } \\
120 \text { ECTS }\end{array}$ & $\begin{array}{l}\text { Hours for } \\
\text { individual study / } \\
\text { Three-year } \\
\text { bachelor degree }\end{array}$ \\
\cline { 2 - 5 } & Credits for FLL & hours & Credits for FLL & hours \\
\hline $\begin{array}{l}\text { Electrical Power } \\
\text { Electrical } \\
\text { Engineering and } \\
\text { Electromechanics }\end{array}$ & $\begin{array}{l}5 \text { ECTS credits (150 } \\
\text { hours) / 80 hours of } \\
\text { in-class study }\end{array}$ & 70 hours & $\begin{array}{l}4 \text { ECTS credits / } 40 \\
\text { hours of in-class } \\
\text { study }\end{array}$ & 80 hours \\
\hline $\begin{array}{l}\text { Agricultural } \\
\text { Engineering }\end{array}$ & $\begin{array}{l}5 \text { ECTS credits (150 } \\
\text { hours) / 80 hours of } \\
\text { in-class study }\end{array}$ & 70 hours & $\begin{array}{l}4 \text { ECTS credits / } 40 \\
\text { hours of in-class } \\
\text { study }\end{array}$ & 80 hours \\
\hline
\end{tabular}

The table shows that 150 hours (Four-year bachelor degree) and 120 hours (Three-year bachelor degree) are given for EFL with the students of engineering specialties in our university. $46 \%$ and $67 \%$ of hours are given for individual study. The analysis of EFL syllabuses of the leading technical universities in Ukraine (the National University of Life and Environmental Sciences, V.I. Vernadsky Taurida National University, Vinnytsia National Agrarian University, Ternopil Ivan Puluj National Technical University) makes it possible to confirm that the total number of hours for a foreign language study in is almost the same. The National University of Life and Environmental Sciences, for example, has 6 credits for FLL with the students majoring in Agricultural Engineering and Transport technology. V.I. Vernadskyi Taurida National University provides 8 credits for intensive language learning with students majoring in Electrical Power Engineering, Electrical Engineering and Electro mechanics. We attempted to compare the total number of hours given for EFL at our national technical universities with the hours offered by authoritative international language centers. According to the guide to Cambridge ESOL exams, level B2 can be achieved after approximately 180-200 hours of learning, B1 can be achieved after approximately 375 hours of study and level B2 needs about 500-600 hours of language learning.

In practice, only $10 \%$ of students of Technical and Engineering Department at our university passed general foreign language testing after school. So the EFL level of the majority of our students is about A1-A2.

Even if the first-year students are supposed to have a B1 level of the foreign language (the Concept of EFL in Ukrainian High Schools states that all the bachelor graduates must have B2 language competence till 2023 [4]). To acquire such language level they need about 600 hours for in-class and out-of-class (individual). This number of hours is in four times lower than necessary for effective language learning. The students 
of four-year and three-year bachelor degree programme have 150 (80 in-class study and 70 hours of individual study) and 120 (40 and 80 correspondingly). As soon as EFL is studied (since 2019) for 4 semesters (2 academic years) and 2 semesters ( 1 year) for students of the threeyear bachelor programme, the rest of their study the students have to attend language clubs and courses not to lose the language skills.

Thus, low foreign language level of students majoring in Engineering, insufficient quantity of hours for language learning and two-year gap when the students don't practice the foreign language can't but influence the quality of education process in High School. As far as university teachers can't increase learning hours, the teaching staff has to incorporate such teaching strategies that could benefit effective, quick and interesting foreign language learning. These strategies should also enhance students' further language self-study. Our university teachers try to examine and provide into the teaching process [5] most progressive approaches and strategies.

Foreign language teachers in our university experimentally proved and recommended the university to integrate profession-based podcasts with students of technical universities. This innovation will help to improve students' listening and speaking, to provide the participants of the educational process with new vocabulary, to encourage the interaction with engineering community and independent student learning outside the classroom [6].

Moreover, our colleagues had the experience of using Quizlet platform with university students at intensive language courses. The results of the research showed that the principles of integrated learning, cognitive visualization and spaced repetition technique enabled to increase students' vocabulary acquisition at 7\% [7].

One of the most difficult items the students deal with at Technical high School is professional vocabulary in EFL. The students have to master the professional vocabulary in short terms and we would like to approve using Quizlet in professional vocabulary acquisition with the students majoring in Engineering.

We examined the recent research papers (2010-2018) into the effects of MALL tools into vocabulary acquisition. A substantial amount of research has been conducted upon traditional and digital [8] methods of vocabulary acquisition. Azabdaftari and Mozaheb (2012) compared the use of two strategies for vocabulary learning (i.e. flashcards and m-learning) and the findings of their research showed that the use of mobile phones for language learning and vocabulary learning would be a better strategy compared to the use of other paramount techniques, such as flashcards. When investigating the issue of vocabulary learning and providing the survey, the researchers reported that "students better remember the words studied online" [9]. By contrast, Lees states that "vocabulary learning using digital word cards, such as Quizlet, on smartphones produced roughly equivalent results when compared with the more traditional paper word-cards" [10].

In his study, Chien (2015) compared freshmen's perceptions of and attitudes toward three online vocabulary flashcard websites, Quizlet, Study Stack, and Flashcard Exchange. The main results of Chein's study were the following findings: "first, these three online vocabulary flashcard websites mainly focused on Nation's (1994) form and words' meaning. These online exercises and flashcards met eight of Nakata's 17 criteria. Second, participants held positive attitudes toward learning and improving their vocabulary abilities via online flashcards and their related activities") [11]. In research from Godwin -Jones (2012) Mall platforms assist the learner autonomy and provide means for learners to combine formal and informal learning [12]. Mclean, Hogg and Rush examined efficiency of Word Engine for vocabulary acquisition. They suggest that that assigning online vocabulary platform use for out-of-class work contributes relatively quickly to learners' receptive vocabulary knowledge [13]. According to Martinez and Schmitt "technology is one more medium through which vocabulary learning and teaching can be enhanced". However, "we are still very far away from being able to claim that electronic media can play as large a role in vocabulary acquisition as, say, reading a variety of authentic material on a regular basis" [14] and recommended to use Quizlet in EFL classroom. We should admit that research on the effects of web-based language platforms for EFL students of technical high school still lack.

The aim of the present study is to examine technical high students' attitude towards technology, to experimentally prove that up-to-date digital tools such as Quizlet vocabulary learning platform [15] can benefit professional vocabulary acquisition with the male high school students.

\section{RESEARCH METHOD}

This is an experimental study. The survey was conducted based on the Engineering and Technical Department of State Agrarian and Engineering University in Podilia. 96 first-year students majoring in Agricultural Engineering, Electrical Power Engineering, Electrical Engineering and Electro mechanics who learn English for two semesters were enrolled in the experiment. The experiment consists of several stages: the student questionnaire that focuses upon six aspects of attitude towards technology namely: gender issues, Internet access, uses of the computer, frequency of computer use, experience of computer-assisted learning in school and college, activation of the Quizlet based professional vocabulary learning for the pool of 49 students of experimental group and post-experimental testing. The students of the control group $(n=47)$ didn't 
use MALL (mobile assisted language learning platform) in the EFL classroom. During spring semester we had 14 periods 45 minutes each (one period a week). Both groups had profession-based EFL classes and used "Technical English vocabulary and grammar". The experimental group had Quizlet based activities each lesson while the control group worked according to traditional EFL learning methods. Both groups had postexperiment testing of the same difficulty. The final testing consisted of three tasks. The first two tasks asked the students to match the words that go together and complete the sentences below or to match a word with the correct definition. The third one was a creative task.

\section{RESULTS}

To determine students' attitude towards technology we designed a questionnaire.

\section{Student technology survey}

1. Do you have access to the Internet through mobile phone, laptop at the university?

- mobile phone

- laptop

- none

2. I use a computer to (select all that apply):

- Access class materials

- Create/edit digital photos/movies

- Create multimedia presentations/slide show presentations

- Create Websites

- Social Media (Facebook, Twitter, Instagram or any other sort of social media)

- Download and Listen to music through the internet

- Find information on the Internet

- Take Notes

- Take a test or quiz, on-line courses, seminars

- Watch movies and shows for entertainment

- Work with other students on group projects

- Play games

- For business

- Stay connected to what is happening in my world

- In a typical day, how many hours do you spend on the computer?

- 1-2

- $2-5$

- More than 5

3. How often did you use a computer in your classes?
- Daily

- Weekly

- Monthly

- Never

The analysis of the questionnaire answers showed that only male students participated in the experiment. $86 \%$ of the respondents have access to the Internet through smartphones, $10 \%$ have laptops at the dormitory and can bring if it is necessary with them, $4 \%$ have no access to the Internet. We put the computer-based activities starting from most frequent to least frequent ones.

- $\quad$ Social Media (Facebook, Twitter, Instagram or any other sort of social media);

- $\quad$ Play games;

- Watch movies and shows for entertainment;

- Stay connected to what is happening in my world;

- Create/edit digital photos/movies;

- Find information on the Internet;

- Take a test or quiz, on-line courses;

- Take Notes;

- Create Websites.

What is important, nobody has chosen the following options: Access class materials, Create multimedia presentations/slide show presentations, Work with other students on group projects and Take a test. We should admit that teenagers use mobile and computer devices, primarily, for entertainment. The level of computer literacy is extremely low, although most respondents spend about 6-7 hours surfing the Net.

Providing Quizlet in EFL classroom will help the students to use the potential of MALL tools in their studying. We are sure that such platforms are good, first of all, for male students. It should be mentioned that all respondents in our survey are male students. We noticed that boys are not always disciplined in comparison with the girls, especially when we talk about student's vocabulary notebooks. As a rule, the girls write down all the words, transcription, definition, collocations, synonyms and antonyms. Keeping a vocabulary notebook is perceived as boring for learners, especially male students. Quizlet is a great alternative to traditional vocabulary notebooks and is an ideal online vocabulary for male students because the procedure of writing and remembering the words is more interesting than working with paper vocabulary. It is experimentally proved that male students learn better by seeing the board or computer screen. This platform allows dealing with an unknown word through different modes.

During our experiment, we didn't use ready-made flashcards, but created engineering flashcards modes by ourselves during lesson time based on Technical English vocabulary and grammar by Nick Brieger and Alison Pohl [16]. The terms that concern Automotive, 
Engineering, Electrical, Energy, Construction are very difficult to remember. The process of creating flashcards also assists in remembering a new word with the students. translation in Ukrainian and adding the picture. Here is the screen of Quizlet page with the words and pictures we added to the flashcards. (Figure 1)

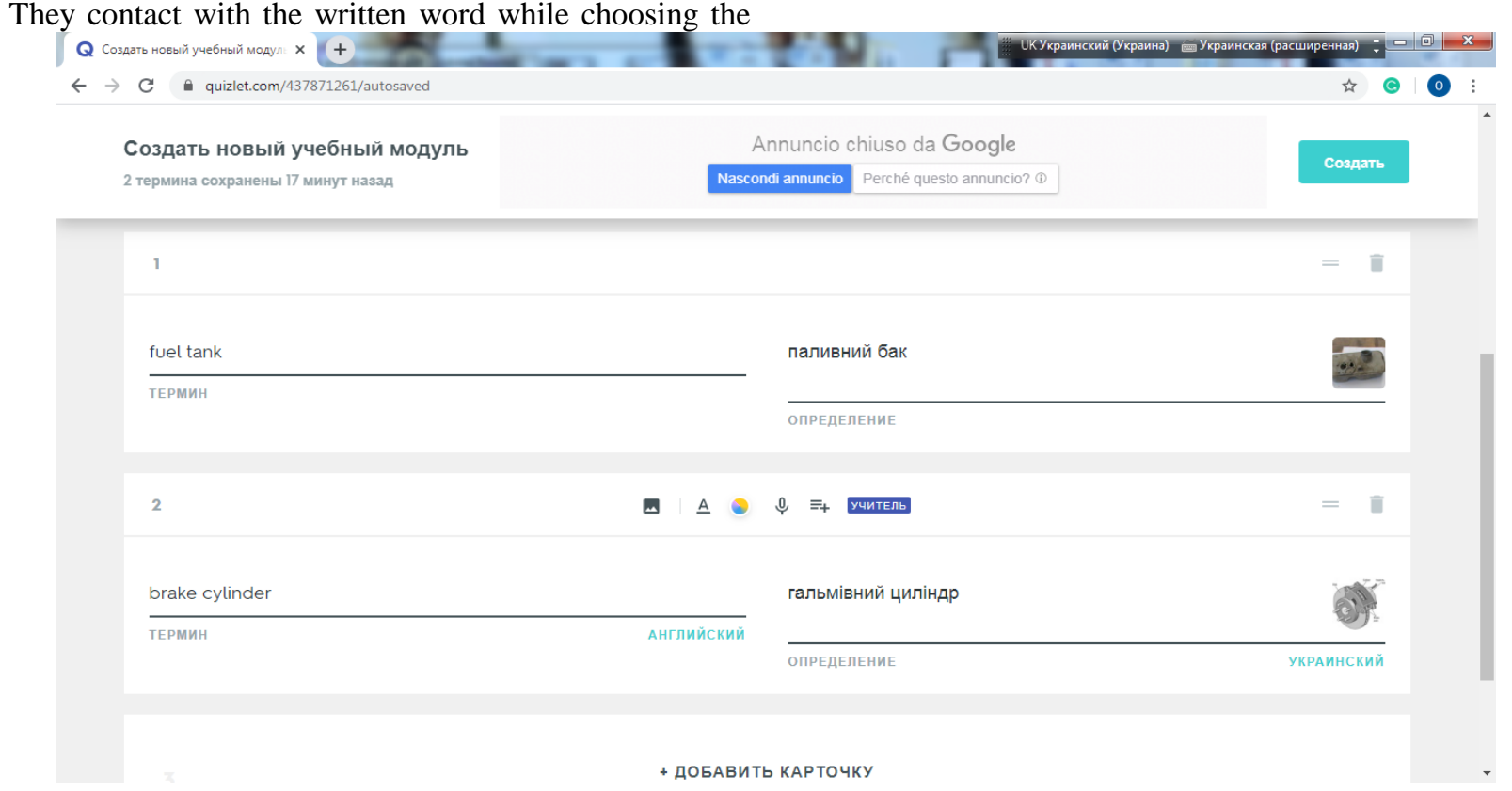

Figure 1 Quizlet engineering flashcards

Having created the set of flashcards we did vocabulary exercises based on gradual increasing retrieval efforts. The easiest exercises and games were given for homework. What we especially liked about Quizlet is the fact that this on-line platform focuses on the words students find it difficult to remember. As soon as most students remembered the words and the platform showed their progress, we did vocabulary exercises in our textbook or tests, designed by the teacher, to check the level of vocabulary acquisition with the students.

Quizlet doesn't provide the foreign language learners with the context, so second and third exercises in "Technical English vocabulary and grammar" are focused on professional vocabulary application and using the language around the practical context.

We had an opportunity to check the students' progress in Quizlet tests. The students were asked to label the diagram, to fill in the blanks in an email from a company to a customer, to create an advertisement about the advantages of harvesting machine LK-85, John Greaves reaper, sunflower reaper, mineral fertilizer spreader 'Favorite". The final test was more difficult due to new professional vocabulary the students were supposed to learn. The results of the final testing are given in Table 2.

As shown in Table 2, there is a difference between the mean scores of the students who were taught English vocabulary based on Quizlet platform (the experimental group) and those who were taught English vocabulary by using traditional methods (control group). The results obtained from professional engineering vocabulary revealed little change in favor of the experimental group. However, participants in the experimental group demonstrated gains in grade point average. It is 14.7 in comparison to 6.58 of the control group. It means that students of the experimental group showed better vocabulary performance than students of the control group.

Besides, the experiment helped us to improve students' attendance. Absenteeism negatively influences academic performance. Our experiment was also an attempt to motivate the students to learn a foreign language and improve their academic outcomes through regular class attendance. It turned out that Quizlet can be used to keep attendance high in the EFL classroom. During our experiment, we captured and tracked students' attendance in both groups. At the end of the experiment, we compared the number of students who attended the classes and arrived at a conclusion that providing such online learning tool as Quizlet can improve students' attendance. The experimental group showed more than twice higher average attendance compared to the control group. To our mind, Quizlet inspired the students to attend classes not only due to its digital structure. The process of creating Quizlet flashcards in the team, gamification, exchanging information on vocabulary via social media group we created with the students of experimental group, the ability to share its progress in profession acquisition with your classmates with the help of Quizlet engaged the students of the experimental group and made them active participants of learning. The results are listed in Table 3. 
Table 2. Control and experimental groups final test achievement scores (Maximum score is 40)

\begin{tabular}{|c|c|c|c|}
\hline \multicolumn{4}{|c|}{ Final testing } \\
\hline \multicolumn{2}{|c|}{$\begin{array}{c}\text { Experimental } \\
\text { Group } \\
(n=49)\end{array}$} & \multicolumn{2}{|c|}{$\begin{array}{l}\text { Control } \\
\text { Group } \\
(n=47)\end{array}$} \\
\hline Number of students & Score & Number of students & Score \\
\hline 1 & 31 & 1 & 28 \\
\hline 3 & 27 & 1 & 27 \\
\hline 2 & 26 & 1 & 25 \\
\hline 6 & 24 & 5 & 24 \\
\hline 6 & 23 & 6 & 21 \\
\hline 5 & 21 & 8 & 17 \\
\hline 7 & 20 & 9 & 16 \\
\hline 7 & 17 & 8 & 14 \\
\hline 8 & 16 & 7 & 12 \\
\hline 4 & 12 & 2 & 11 \\
\hline Average & 20.12 & Average & 17.53 \\
\hline
\end{tabular}

Table 3. Students' attendance in the experimental and control groups

\begin{tabular}{|c|c|c|c|c|c|c|}
\hline Category & \multicolumn{2}{|c|}{$\begin{array}{c}\text { Number of } \\
\text { students }\end{array}$} & \multicolumn{2}{c|}{$\begin{array}{c}\text { Number of } \\
\text { students }\end{array}$} & $\begin{array}{c}\text { Difference, } \\
\%\end{array}$ & Difference, \% \\
\cline { 2 - 5 } & \multicolumn{2}{|c|}{$\begin{array}{c}\text { Experimental } \\
\text { group }\end{array}$} & \multicolumn{2}{|c|}{ Control group } & $\begin{array}{c}\text { Experimental } \\
\text { group }\end{array}$ & Control group \\
\cline { 2 - 6 } & before & after & before & After & $16.5 \%$ & $7 \%$ \\
\hline Attendance & $\begin{array}{c}38 / \\
77.5 \%\end{array}$ & $\begin{array}{c}36 / \\
94 \%\end{array}$ & $\begin{array}{c}37 \% \\
78 \%\end{array}$ & $85 \%$ & \\
\hline
\end{tabular}

\section{DISCUSSION AND CONCLUSION}

In 2014 Ukraine signed the association agreement with the EU. Since that time all spheres of life are focused on European integration. Foreign language fluency is the most important factor that can help to integrate university students and teachers into a unified educational framework. Now becoming fluent in English is at the core of Ukrainian national policy strategy. However, technical university students in our country still have a low level of language proficiency. Nowadays it is rare to find a foreign language class that doesn't use technology. But what is important, almost $80 \%$ of students in our university come from rural territories schools and colleges. A questionnaire with the engineering students showed that they have the experience of using technology, but only for entertainment, communication on social media and watching the video and listening to music. The present study is an attempt to examine the current situation and issues related to ICT utilization in Technical High School. We shared our experience in using Quizlet language platform in EFL professional learning with the male high school students. Our study has affirmed that such type of foreign language learning platform like Quizlet (available freely on the internet) proved to be effective in professional vocabulary acquisition especially with male students of engineering specialties. It is explained, primarily, by the fact that Quizlet is a digital alternative to traditional vocabulary 
notebooks that due to its visual and audio characteristics helped to motivate and engage male engineers in gamebased learning activities. Besides, Quizlet based vocabulary learning helped to increase students' social skills and create positive relationships with peers and teachers. Also, implementation of Quizlet in EFL learning helped to improve students' attendance at $16.5 \%$ compared to only $7 \%$ of the control group. The above arguments imply that Quizlet should be adopted and implemented into university EFL learning with the students of Technical High School. However, additional research will be needed to evaluate what period of learning time is appropriate for successful professional acquisition in technical high school.

\section{REFERENCES}

[1] Sathiya Devi S. and Parthasarathy G. (2019), "Feature Engineering based Approach for Prediction of Movie Ratings", International Journal of Information Engineering and Electronic Business, vol. 11, no. 6, pp. 24-31. DOI: 10.5815/ijieeb.2019.06.04

[2] Educational and professional program "Agricultural engineering" of the first level of higher education in specialty 208 "Agricultural engineering", field of knowledge 20 "Agricultural Sciences and Food Production", Qualification: Bachelor of Agricultural engineering, (2019), available at: https://pdatu.edu.ua/images/navchalnarobota/opp/opp-b-itf-5-pmoav-2.pdf

[3] Educational and professional program "Electric power engineering, electrical engineering and electromechanics" of the first level of higher education in specialty 141 "Electric power engineering, electrical engineering and electromechanics", branch of knowledge 14 "Electrical engineering". Qualification: Bachelor of Power Engineering, Electrical Engineering and Electromechanics, (2019), Electronic Source, available

https://pdatu.edu.ua/images/navchalna-

robota/opp/opp-b-itf-1-power.pdf

[4] Conceptual fundamentals of the State policy on development of the English language in higher education, (2019), Electronic Source, available at: https://mon.gov.ua/ua/news/mon-stvorilokoncepciyu-rozvitku-anglijskoyi-v-universitetahu-dodatku-riven-v1-obovyazkova-umova-vstupuv2-vipusku-vikladannya-profilnih-disciplininozemnoyu-ta-movni-skriningi

[5] Gang Cen and JunYan Luo (2012), "Design of a Teaching Process Monitoring and Management
System", IJEME, vol. 2, no. 4, pp. 28-33. DOI: 10.5815/ijeme.2012.04.05

[6] Chaikovska, O., Zbaravska, L. and Bilyk, T. (2019), "Podcasts in teaching EFL for students majoring in engineering" Proceedings of the Conference on Engineering for Rural Development, Jelgava, Latvia, DOI: 10.22616/ERDEV2019.18.N344

[7] Chaikovska, O. and Zbaravska, L. (2020), "The efficiency of Quizlet-based EFL vocabulary learning in preparing undergraduates for state English exam", Advanced Education. Special issue, vol. 14, pp. 84-90. DOI https://doi.org/10.20535/2410-8286.197808

[8] Mubasher Hassan M. and Tabasum Mirza (2021), "The Digital Literacy in Teachers of the Schools of Rajouri (J\&K)-India: Teachers Perspective", International Journal of Education and Management Engineering, vol. 11, no. 1, pp. 28-40. DOI: $10.5815 /$ ijeme.2021.01.04

[9] Azabdaftari, B. and Mozaheb, A. (2012), "Comparing vocabulary learning of EFL learning by using two different strategies: mobile learning vs. flashcards", vol. 20, no. 2, EUROCALL Review, pp. 48-

59. DOI: https://doi.org/10.4995/eurocall.2012.11 377

[10] Lees, D. (2015), “A brief comparison of digital-and self-made word cards for vocabulary learning", Kwansei Gakuin University Humanities Review, vol. 18, pp. 59-71.

[11] Chien, C. W. (2015), "Analysis the effectiveness of three online vocabulary flashcard websites on 12 learners' level of lexical knowledge", English Language Teaching, vol. 8, no. 5, pp. 111-121. DOI: http://dx.doi.org/10.5539/elt.v8n5p111.

[12] Godwin-Jones, R. "Mobile apps for language learning. Language Learning \& Technology", vol. 15 , no 2 , pp. 2-11.

[13] McLean, S., Hogg, N. and Rush, T. (2013), "Vocabulary learning through an online computerized flashcard site", The JALT CALL Journal, vol. 9, no. 1, pp. 79-98. DOI: 10.29140/jaltcall.v9n1.149

[14] Martinez, R. and Schmitt, N. (2010), "Invited commentary: Vocabulary", Language Learning \& Technology, vol. 14, no. 2, pp. 26-29. DOI: https://doi.org/10125/44212

[15] Lina Yu (2011), "Work-Integrated Teaching Mode Based on An E-learning Platform", IJEME, vol. 1, no. 4, pp. 34-40. DOI: 10.5815/ijeme.2011.04.06

[16] Brieger, N. and Pohl, A. (2006), "Technical English vocabulary and grammar", Summertown Publishing. 